\title{
Stimulation of Methanogenesis by Slurries of Saltmarsh Sediment after the Addition of Molybdate to Inhibit Sulphate-reducing Bacteria
}

\author{
By IBRAHIM M. BANAT, DAVID B. NEDWELL* AND M. TALAAT BALBA \\ Department of Biology, University of Essex, Colchester CO4 3SQ, Essex, U.K.
}

(Received 26 April 1982; revised 24 June 1982)

\begin{abstract}
The addition of $20 \mathrm{~mm}$-molybdate to sediment slurry in order to inhibit sulphate-reducing bacteria increased the amount of methane formed. Only a small proportion $(7.8 \%)$ of the total methane came from the $\mathrm{H}_{2}+\mathrm{CO}_{2}$ pathway, while methanogenesis from acetate was negligible. Conversion of. ${ }^{14} \mathrm{C}$-labelled formaldehyde, methanol and methionine to ${ }^{14} \mathrm{CH}_{4}$ by sediment slurry in the presence of molybdate showed that these were potential precursors of the additional methane, although lack of adequate analytical techniques precluded establishment of the quantitative significance of this turnover; $\left[{ }^{14} \mathrm{C}\right]$ formate was not converted to ${ }^{14} \mathrm{CH}_{4}$. It is suggested that inhibition of sulphate-reducing bacteria by molybdate immediately increased methanogenesis from formaldehyde, methanol and methionine, and to some extent from $\mathrm{H}_{2}+$ $\mathrm{CO}_{2}$. There was also evidence for longer term development of an increased methanogenic bacterial population when there was no competition from the sulphate-reducing bacteria for available nutrients.
\end{abstract}

\section{INTRODUCTION}

Molybdate is a potent inhibitor of sulphate-reducing bacteria (Peck, 1959) and has been used as an inhibitor of sulphate reduction in natural microbial communities, including anaerobic sediments (Oremland \& Taylor, 1978). A number of workers have used $20 \mathrm{~mm}$-molybdate specifically to inhibit sulphate-reducing bacteria in order to investigate their role in carbon flow in anaerobic sedimentary communities, particularly with regard to competition between sulphate-reducing bacteria and methanogenic bacteria (Oremland \& Taylor, 1978; Banat et al., 1981 ; Sørensen et al., 1981). It has previously been suggested (Winfrey \& Zeikus, 1977; Abram \& Nedwell, $1978 b$; King \& Wiebe, 1980) that the sulphate-reducing bacteria preferentially use both $\mathrm{H}_{2}$ and acetate in competition with the methanogens. Several workers (Oremland \& Taylor, 1978; Banat et al., 1981, Sørensen et al., 1981; Nedwell \& Banat, 1981) have reported that inhibition of sulphate-reducing bacteria by molybdate in slurries of anaerobic sediments stimulated the rate of methane formation, and also led to the accumulation of $\mathbf{H}_{2}$ and acetate (Sørensen et al., 1981; Nedwell \& Banat, 1981), thus apparently supporting the hypothesis of competition for these substrates.

The present work was undertaken to investigate whether the additional methane formed upon addition of molybdate to sediment slurry could be accounted for by the stimulation of the $\mathrm{H}_{2}+$ $\mathrm{CO}_{2}$ or the acetate pathways to methane.

\section{METHODS}

Preparation of sediment slurry. Slurry of $50 \%(\mathrm{v} / \mathrm{v})$ sediment in deoxygenated aged seawater was prepared with the precautions to ensure anaerobiosis described by Banat $e t$ al. (1981). The sediment used was taken from the top 0-5 cm layer at a site in the bottom of a saltmarsh creek in the Colne Point saltmarsh, Essex, U.K. (Nedwell \& Abram, 1978). Samples of slurry $(65 \mathrm{ml})$ were dispensed into $150 \mathrm{ml}$ Erlenmeyer flasks sealed with subaseals (Fisons) and gassed with either $\mathrm{N}_{2} / \mathrm{CO}_{2}(80: 20 \%, v / v)$ or $\mathrm{H}_{2} / \mathrm{CO}_{2}(80: 20 \%, v / v)$ (British Oxygen Company, 
U.K.). The flasks were incubated at $22^{\circ} \mathrm{C}$ on an orbital platform shaker at a speed just sufficient to maintain sediment particles in suspension. Each experiment was carried out with a freshly prepared batch of slurry.

Uptake of $\mathrm{H}_{2}$ and $\mathrm{CH}_{4}$ formation. Duplicate flasks of slurry were set up for each of the following treatments under an $\mathrm{N}_{2} / \mathrm{CO}_{2}$ atmosphere : (a) no additions; (b) with $1 \mathrm{ml} \mathrm{Na} \mathrm{MoO}_{4} .2 \mathrm{H}_{2} \mathrm{O}$ solution to give a final concentration of 20 mM-molybdate; $(c)$ with $20 \mathrm{~mm}$-molybdate $+0.05 \%$ (v/v) chloroform to eliminate methanogenesis (Bauchop, 1967); (d) with chloroform $(0.05 \%, v / v)$. A second series of duplicate flasks, with identical treatments to the above, were set up under $\mathrm{H}_{2} / \mathrm{CO}_{2}$.

The flasks were incubated and subsamples $(50 \mu \mathrm{l})$ of the gas head spaces were periodically removed via the subaseals. Subsamples were analysed for methane concentration by injection into a Perkin-Elmer F33 gas chromatograph with flame-ionization detector $(2 \mathrm{~m} \times 3 \mathrm{~mm}$ o.d. stainless steel column packed with Poropak $\mathrm{N}$; isothermally at $70{ }^{\circ} \mathrm{C} ; \mathrm{N}_{2}$ carrier gas at $30 \mathrm{ml} \mathrm{min}^{-1}$ ). In addition, further subsamples were analysed for $\mathrm{H}_{2}$ concentration in order to detect any $\mathrm{H}_{2}$ uptake by the slurry under $\mathrm{H}_{2} / \mathrm{CO}_{2}$. Analyses for $\mathrm{H}_{2}$ were by injection of 50 $\mu 1$ subsamples of the head space into a Perkin-Elmer F33 gas chromatograph with a thermistor detector $(2 \mathrm{~m} \times$ $3 \mathrm{~mm}$ o.d. stainless steel column packed with $80-100$ mesh silica gel; isothermally at $100{ }^{\circ} \mathrm{C} ; \mathrm{N}_{2}$ carrier gas at $20 \mathrm{ml} \mathrm{min}^{-1}$ ).

Experiments with $\mathrm{H}^{14} \mathrm{CO}_{3}^{-}$and $\left[\mathrm{U}-{ }^{14} \mathrm{C}\right]$ acetate. Four flasks were set up with a $\mathrm{N}_{2} / \mathrm{CO}_{2}$ atmosphere and molybdate (20 mM) was added to two of the flasks. The flasks were incubated for $24 \mathrm{~h}$ and $\mathrm{CH}_{4}$ concentrations in the head spaces were then analysed to ensure that the added molybdate had stimulated the rate of formation of $\mathrm{CH}_{4}$. Following this confirmation, $200 \mu \mathrm{l}$ of $\mathrm{H}^{14} \mathrm{CO}_{3}^{-}$solution $\left[10 \mu \mathrm{Ci} \mathrm{m}{ }^{-1} ; 0.1 \mathrm{mCi}(3.7 \mathrm{MBq}) \mathrm{mmol}^{-1}\right]$ were then injected into each flask and the incubation continued for a further $3 \mathrm{~d}$. The gas head space of each flask was periodically sampled and $50 \mu \mathrm{l}$ subsamples injected into a Pye-Unicam GCD gas chromatograph with flameionization detector $\left(2 \mathrm{~m} \times 4 \mathrm{~mm}\right.$ o.d. glass column packed with silica gel, 80-100 mesh) at $100{ }^{\circ} \mathrm{C} ; \mathrm{Ar} / \mathrm{CO}_{2}$ $(95: 5 \%, \mathrm{v} / \mathrm{v})$ carrier gas (British Oxygen Company, U.K.) at $50 \mathrm{ml} \mathrm{min}^{-1}$. At the end of the gas chromatography column a $1: 1$ stream splitter directed half of the effluent gas stream to the flame-ionization detector and the other half to a gas proportional counter (Model 504, E.S.I. Nuclear, U.K.). The gas stream to the counter was first passed through an oven packed with $\mathrm{CuO}$ at $700{ }^{\circ} \mathrm{C}$ to oxidize any carbon compounds to $\mathrm{CO}_{2}$, and then radioactivity in the $\mathrm{CH}_{4}$ and $\mathrm{CO}_{2}$ peaks was measured as ${ }^{14} \mathrm{CO}_{2}$ in a flow-through counting chamber (Balba \& Nedwell, 1982). The silica gel gas chromatography column adequately separated $\mathrm{CH}_{4}$ and $\mathrm{CO}_{2}$. Even though the flame-ionization detector did not respond to $\mathrm{CO}_{2}$, radioactivity in the $\mathrm{CO}_{2}$ peak was detected and counted by the gas proportional counter.

A further subsample of the sediment slurry was used to measure titrimetrically the total carbonate content of the slurry (Gran, 1952).

Another set of flasks was used to repeat this experiment, with the same batch of slurry, with $200 \mu 1$ of [U-14 C]acetate solution $\left[10 \mu \mathrm{Ci} \mathrm{m} \mathrm{m}^{-1} ; 58 \mathrm{mCi}(2 \cdot 15 \mathrm{GBq}) \mathrm{mmol}^{-}\right]$injected into each flask. The acetate concentration in the slurry was measured by ether extraction of an acidified sample of centrifuged slurry and injection of subsamples of the ether extract into a gas chromatograph (Balba \& Nedwell, 1982). The concentration of acetate was determined by comparison with extracted aqueous standards.

Methane formation in the presence of fluoroacetate. Two pairs of flasks were set up under $\mathrm{N}_{2} / \mathrm{CO}_{2}$. To one pair 20 mM-molybdate was added, while to the second pair $20 \mathrm{mM}$-molybdate + fluoroacetate ( $5 \mathrm{mM}$ final concentration) was added. The flasks were incubated as described previously and the gas head spaces periodically sampled and analysed for $\mathrm{CH}_{4}$.

Experiments with ${ }^{14} \mathrm{C}$-labelled formate, formaldehyde, methanol and methionine. Similar experiments to those described above were carried out in which flasks were injected with $200 \mu$ volumes of solutions of: (a) sodium $\left[{ }^{14} \mathrm{C}\right]$ formate $\left[20 \mu \mathrm{Ci} \mathrm{ml}^{-1} ; 10 \mathrm{mCi}(0 \cdot 4 \mathrm{GBq}) \mathrm{mmol}^{-1}\right] ;(b)\left[{ }^{14} \mathrm{C}\right]$ formaldehyde $\left[20 \mu \mathrm{Ci} \mathrm{ml}^{-1} ; 10 \mathrm{mCi}(0 \cdot 4 \mathrm{GBq})\right.$ $\left.\mathrm{mmol}^{-1}\right]$; (c) $\left[{ }^{14} \mathrm{C}\right]$ methanol $\left[10 \mu \mathrm{Ci} \mathrm{ml}^{-1} ; 58 \mathrm{mCi}(2 \cdot 15 \mathrm{GBq}) \mathrm{mmol}^{-1}\right]$; or $(d)[$ methyl-14 $\mathrm{C}]$ methionine $[10 \mu \mathrm{Ci}$ $\left.\mathrm{ml}^{-1} ; 57 \mathrm{mCi}(2 \cdot 1 \mathrm{GBq}) \mathrm{mmol}^{-1}\right)$. All radiotracers were obtained from Amersham. The gas head spaces of flasks were periodically sampled to measure any radioactivity appearing in $\mathrm{CH}_{4}$ or $\mathrm{CO}_{2}$. After $3 \mathrm{~d}$, the slurry was acidified with $5 \mathrm{ml} 6 \mathrm{M}-\mathrm{HCl}$ in order to release all $\mathrm{HCO}_{3}^{-}$as $\mathrm{CO}_{2}$, and the recovery of ${ }^{14} \mathrm{C}$ as either ${ }^{14} \mathrm{CH}_{4}$ or ${ }^{14} \mathrm{CO}_{2}$ was determined. Each experiment was carried out with a separate batch of freshly-prepared slurry. In all the experiments methane formation was measured and similar results were obtained as for the $\mathrm{H}_{2}+\mathrm{CO}_{2}$ /acetate experiment.

These experiments differed from those with $\mathrm{H}^{14} \mathrm{CO}_{3}^{-}$and $\left[\mathrm{U}-{ }^{14} \mathrm{C}\right]$ acetate in that adequate analytical methods were not available to measure the pool size in the sediment slurry of each of these substrates, and only conversion data could therefore be obtained.

$\mathrm{CH}_{4}$ oxidation. Radioactive $\mathrm{CH}_{4}$ was prepared with a culture of unidentified methanogenic bacteria under $\mathrm{H}_{2} / \mathrm{CO}_{2}$ to which $\mathrm{NaH}^{14} \mathrm{CO}_{3}$ was added. When sufficient ${ }^{14} \mathrm{CH}_{4}$ had accumulated in the gas head space of the culture flask, the culture was made strongly alkaline with $5 \mathrm{M}-\mathrm{NaOH}$ in order to absorb any residual ${ }^{14} \mathrm{CO}_{2}$. The gas head space of the culture flask was then checked by injecting a $500 \mu$ l subsample into the gas proportional counter. Only ${ }^{14} \mathrm{CH}_{4}$ and no ${ }^{14} \mathrm{CO}_{2}$ was detected in the gas head space. The ${ }^{14} \mathrm{CH}_{4}$ had an activity of $0.03 \mu \mathrm{Ci} \mathrm{ml}{ }^{-1}$ 
[specific activity $2.2 \mu \mathrm{Ci}(81.4 \mathrm{KBq}) \mathrm{mmol}^{-1}$ ]. Duplicate flasks of slurry were set up under $\mathrm{N}_{2} / \mathrm{CO}_{2}$; while to a second pair of flasks under $\mathrm{N}_{2} / \mathrm{CO}_{2}$ molybdate solution ( $20 \mathrm{mM}$ final concentration) was added. Each flask then had $3 \mathrm{ml}^{14} \mathrm{CH}_{4}$ injected into the head space. The flasks were incubated as before, and the gas head spaces periodically sampled ( $500 \mu \mathrm{l}$ subsamples) to determine whether any conversion of ${ }^{14} \mathrm{CH}_{4}$ to ${ }^{14} \mathrm{CO}_{2}$ could be detected.

\section{RESULTS}

$\mathrm{H}_{2}$ uptake and $\mathrm{CH}_{4}$ formation. The formation of $\mathrm{CH}_{4}$ by slurry in the presence or absence of added molybdate is shown in Fig. 1. The addition of molybdate initially increased the rate of $\mathrm{CH}_{4}$ formation by sediment slurry under either a $\mathrm{N}_{2} / \mathrm{CO}_{2}$ or a $\mathrm{H}_{2} / \mathrm{CO}_{2}$ atmosphere. This initial increase of methanogenesis by molybdate occurred over the first $4 \mathrm{~d}$, following which there was a lag in $\mathrm{CH}_{4}$ generation. After $\mathbf{8} \mathrm{d}, \mathrm{CH}_{4}$ was rapidly generated in both the control and molybdate-treated flasks under $\mathrm{H}_{2} / \mathrm{CO}_{2}$. In all treatments where chloroform was present there was no formation of $\mathrm{CH}_{4}$.

When $\mathrm{H}_{2}$ uptake from the gas head spaces was followed in those flasks under $\mathrm{H}_{2} / \mathrm{CO}_{2}$ (Fig. 2) it was evident that in the molybdate-treated slurries there was little stimulation of $\mathrm{H}_{2}$ uptake during the first $4 \mathrm{~d}$ when rapid methanogenesis occurred. The $\mathrm{H}_{2}$ uptake only increased significantly after $8 \mathrm{~d}$ in both the control and molybdate-treated flasks, coincident with the increase of methanogenesis after this time. In those treatments where chloroform was present this increase in $\mathrm{H}_{2}$ uptake after $8 \mathrm{~d}$ did not occur. The presence of chloroform alone had no effect upon the initial rate of $\mathrm{H}_{2}$ uptake, although it was totally inhibited by molybdate. This agrees with previously reported data (Nedwell \& Banat, 1981) that the sulphate-reducing bacteria, not the methanogenic bacteria, are the major $\mathrm{H}_{2}$-utilizers in the saltmarsh sediment.

Experiments with $\mathrm{H}^{14} \mathrm{CO}_{3}^{-}$and $\left[\mathrm{U}_{-}{ }^{14} \mathrm{C}\right]$ acetate. Methanogenesis was increased by molybdate addition during the first $4 \mathrm{~d}$ of incubation (Fig. 1). Since in each experiment an initial $1 \mathrm{~d}$ incubation was used to confirm increased methanogenesis in the presence of molybdate, a further $3 \mathrm{~d}$ period of incubation was used after radiotracer addition. Three days after addition of either $\mathrm{H}^{14} \mathrm{CO}_{3}^{-}$or $\left[\mathrm{U}^{-14} \mathrm{C}\right]$ acetate only small amounts of radioactivity could be detected in the copious $\mathrm{CH}_{4}$ which had accumulated in those flasks containing molybdate.

The slurry had a total carbonate content of $9610 \mathrm{nmol}$ carbonate (ml slurry) ${ }^{-1}$, and after $3 \mathrm{~d}$, the turnover of $\mathrm{H}^{14} \mathrm{CO}_{3}^{-}$to ${ }^{14} \mathrm{CH}_{4}$ in the presence of molybdate was $0.09 \%$ of the added radioactivity. Therefore it could be calculated that the $\mathrm{H}_{2}+\mathrm{CO}_{2}$ pathway to $\mathrm{CH}_{4}$ accounted for $9610 \times 0.0009=9.61 \mathrm{nmol} \mathrm{CH}_{4}(\mathrm{ml} \text { slurry })^{-1}$. However, total $\mathrm{CH}_{4}$ formation during the same $3 \mathrm{~d}$ period was $111 \mathrm{nmol} \mathrm{CH}_{4}$ (ml slurry) ${ }^{-1}$ and the $\mathrm{H}_{2}+\mathrm{CO}_{2}$ pathway therefore accounted for only $9.61 / 111 \times 100=7.8 \%$ of the total $\mathrm{CH}_{4}$ formed.

Similarly, after $3 \mathrm{~d}$ there was a proportionate turnover to ${ }^{14} \mathrm{CH}_{4}$ of only $0.07 \%$ of the added $\left[\mathrm{U}-{ }^{14} \mathrm{C}\right]$ acetate in the presence of $20 \mathrm{~mm}$-molybdate. Acetate concentration in the slurry was 65 $\mathrm{nmol}(\mathrm{ml} \text { slurry })^{-1}$, giving a rate of acetate methanogenesis over $3 \mathrm{~d}$ of $65 \times 0.0007=0.04 \mathrm{nmol}$ $\mathrm{CH}_{4}$ (ml slurry) $)^{-1}$. This was only $0.04 / 111 \times 100=0.04 \%$ of the total $\mathrm{CH}_{4}$ formed during the $3 \mathrm{~d}$ period.

Methane formation in the presence of fluoroacetate. The accumulation of $\mathrm{CH}_{4}$ in the molybdatetreated flasks of slurry was identical whether $5 \mathrm{~mm}$-fluoroacetate was present or not. The result therefore confirmed that acetate was not a significant precursor of the $\mathrm{CH}_{4}$ formed by the molybdate-treated slurry.

Experiments with ${ }^{14} \mathrm{C}$-labelled formate, formaldehyde, methanol or methionine. Table 1 shows the proportional conversion to ${ }^{14} \mathrm{CH}_{4}$ or ${ }^{14} \mathrm{CO}_{2}$ of each of these added substrates after $3 \mathrm{~d}$, in the presence or absence of $20 \mathrm{mM}$-molybdate.

$\mathrm{CH}_{4}$ oxidation. No decrease of radioactivity from the ${ }^{14} \mathrm{CH}_{4}$ in the head spaces of the flasks could be detected in any of the treatments for up to $12 \mathrm{~d}$ of incubation. This showed that ${ }^{14} \mathrm{CH}_{4}$ was not being metabolized by sedimentary bacteria. 


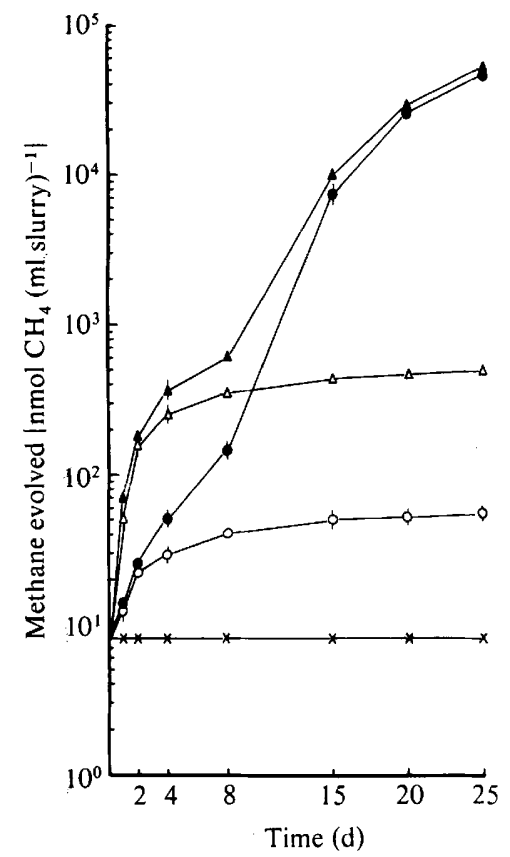

Fig. 1

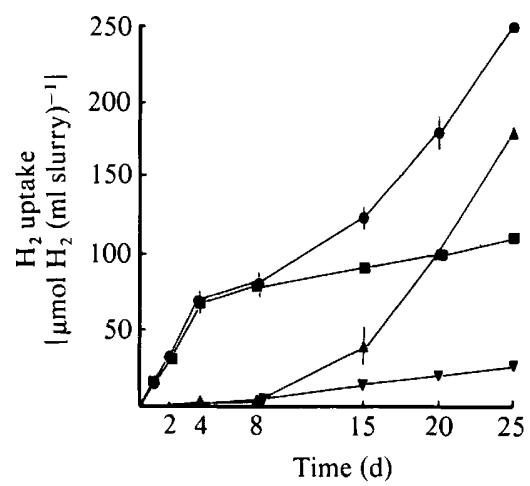

Fig. 2

Fig. 1. Evolution of $\mathrm{CH}_{4}$ by sediment slurry. Solid symbols indicate $\mathrm{H}_{2} / \mathrm{CO}_{2}$ atmosphere; open symbols indicate $\mathrm{N}_{2} / \mathrm{CO}_{2}$ atmosphere. $O$, Controls, with no additions; $\Delta, \triangle$, with $20 \mathrm{mM}$ molybdate; $\times$, with $20 \mathrm{~mm}$-molybdate $+0.05 \%(\mathrm{v} / \mathrm{v})$ chloroform, and also with $0.05 \%(\mathrm{v} / \mathrm{v})$ chloroform only. $\mathrm{CH}_{4}$ was not formed in either of the flasks containing chloroform. Bars indicate spread of duplicates.

Fig. 2. $\mathrm{H}_{2}$ uptake from the gas head spaces of flasks by slurry under $\mathrm{H}_{2} / \mathrm{CO}_{2}$ atmosphere. - Control

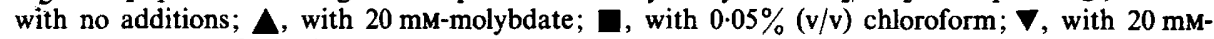
molybdate $+0.05 \%(\mathrm{v} / \mathrm{v})$ chloroform. Bars indicate spread of duplicates.

\section{Table 1. Conversion of potential precursors to $\mathrm{CH}_{4}$ by sediment slurry}

The conversion of ${ }^{14} \mathrm{C}$-labelled precursors to ${ }^{14} \mathrm{CH}_{4}$ or ${ }^{14} \mathrm{CO}_{2}$ was measured in the presence and absence of 20 mM-molybdate. Measurements were made after $3 \mathrm{~d}$, as it was over this period that methanogenesis was enhanced by $20 \mathrm{~mm}$-molybdate.

\begin{tabular}{|c|c|c|c|c|}
\hline \multirow[b]{3}{*}{ Radiotracer } & \multicolumn{4}{|c|}{ Recovery of added radioactivity $(\%)$} \\
\hline & \multicolumn{2}{|c|}{ Without molybdate } & \multicolumn{2}{|c|}{ With $20 \mathrm{~mm}$-molybdate } \\
\hline & ${ }^{14} \mathrm{CH}_{4}$ & ${ }^{14} \mathrm{CO}_{2}$ & ${ }^{14} \mathrm{CH}_{4}$ & ${ }^{14} \mathrm{CO}_{2}$ \\
\hline$\left[{ }^{14} \mathrm{C}\right]$ Formate & 0 & $45 \cdot 0$ & 0 & $79 \cdot 0$ \\
\hline$\left[{ }^{14} \mathrm{C}\right]$ Formaldehyde & 0 & $4 \cdot 8$ & $5 \cdot 2$ & $34 \cdot 1$ \\
\hline$\left[{ }^{14} \mathrm{C}\right]$ Methanol & 0.91 & $96 \cdot 1$ & $26 \cdot 0$ & $47 \cdot 0$ \\
\hline$\left[\right.$ methyl $\left.{ }^{14} \mathrm{C}\right]$ Methionine & 0 & $53 \cdot 0$ & $12 \cdot 6$ & $23 \cdot 1$ \\
\hline
\end{tabular}

\section{DISCUSSION}

The results of the first experiment showed that molybdate addition initially increased methanogenesis from sediment slurry to an equal extent under both $\mathrm{N}_{2} / \mathrm{CO}_{2}$ and $\mathrm{H}_{2} / \mathrm{CO}_{2}$. This suggested that the source of the extra $\mathrm{CH}_{4}$ was not from the $\mathrm{H}_{2}+\mathrm{CO}_{2}$ pathway. Also, the lack of any stimulation of $\mathrm{H}_{2}$ uptake by molybdate (Fig. 2) during this initial $4 \mathrm{~d}$ period supported this contention. It was only after $8 \mathrm{~d}$ that $\mathrm{H}_{2}$ uptake and methanogenesis greatly increased from 
slurry under $\mathrm{H}_{2} / \mathrm{CO}_{2}$, suggesting that methanogenesis from this pathway was initially limited by low numbers of active methanogenic bacteria. The $8 \mathrm{~d}$ lag before methanogenesis increased was presumably the time required for the population of methanogens to respond to the enhanced concentrations of $\mathrm{H}_{2}+\mathrm{CO}_{2}$ available in the experimental flasks.

The experiment with added $\mathrm{H}^{14} \mathrm{CO}_{3}^{-}$confirmed quantitatively that the $\mathrm{H}_{2}+\mathrm{CO}_{2}$ pathway was not the major source of the additional $\mathrm{CH}_{4}$ formed during the initial period. Only $7.8 \%$ of the total $\mathrm{CH}_{4}$ formed in the presence of molybdate during the $3 \mathrm{~d}$ after addition of $\mathrm{H}^{14} \mathrm{CO}_{3}^{-}$was from this pathway. Molybdate addition does, however, stimulate the $\mathrm{H}_{2}+\mathrm{CO}_{2}$ pathway to some extent as the $9.6 \mathrm{nmol} \mathrm{CH}_{4}$ (ml slurry) ${ }^{-1}$ formed under $\mathrm{N}_{2} / \mathrm{CO}_{2}$ has to be compared with a total methanogenesis of only $2.8 \mathrm{nmol} \mathrm{CH}_{4}(\mathrm{ml} \text { slurry })^{-1}$ in the control without molybdate.

It has previously been suggested that sulphate-reducing bacteria preferentially oxidize available $\mathrm{H}_{2}$ in competition with methanogenic bacteria (Winfrey \& Zeikus, 1977; Abram \& Nedwell, 1978a; Oremland \& Taylor, 1978) resulting in inhibition of methanogenesis in sulphate-rich environments such as anaerobic marine sediments. The increase in methanogenesis on addition of molybdate has, therefore, been attributed to the removal of this competition (Oremland \& Taylor, 1978; Sørensen et al., 1981; Nedwell \& Banat, 1981). None of these workers used radiotracers, however, and their data and conclusions are therefore less direct than those reported here.

Again, our experiment with [U-14 C]acetate showed quantitatively that only a negligible proportion $(0.04 \%)$ of the $\mathrm{CH}_{4}$ formed in the presence of molybdate was derived from acetate. The experiment with fluoroacetate, an inhibitor of acetate turnover (Banat et al., 1981), confirmed that acetate was also not a significant precursor of the additional $\mathrm{CH}_{\mathbf{4}}$.

Although molybdate addition initially increased $\mathrm{CH}_{4}$ formation, a lag subsequently developed after $4 \mathrm{~d}$ under both $\mathrm{N}_{2} / \mathrm{CO}_{2}$ and $\mathrm{H}_{2} / \mathrm{CO}_{2}$. This suggested that molybdate permitted the rapid metabolism to $\mathrm{CH}_{4}$ of precursors in the sediment which became depleted after $4 \mathrm{~d}$. Formate, formaldehyde and methanol have been proposed as intermediates in the reduction of $\mathrm{CO}_{2}$ to $\mathrm{CH}_{4}$ and have also been shown to be converted to $\mathrm{CH}_{4}$ by various methanogenic bacteria (Wolfe, 1971; Wolfe \& Higgins, 1979). Amino acids such as methionine may also be used as $\mathrm{CH}_{4}$ precursors (Zinder \& Brock, 1978). These, therefore, represented possible alternative precursors for $\mathrm{CH}_{4}$ in the sediment. Our experiments with ${ }^{14} \mathrm{C}$-labelled isotopes of these potential precursors of $\mathrm{CH}_{4}$ showed that in the absence of molybdate they were converted to ${ }^{14} \mathrm{CO}_{2}$, not ${ }^{14} \mathrm{CH}_{4}$ (Table 1). In the presence of molybdate, $\left[{ }^{14} \mathrm{C}\right]$ formate did not give rise to any ${ }^{14} \mathrm{CH}_{4}$, but $5.2 \%$ of the $\left[{ }^{14} \mathrm{C}\right]$ formaldehyde, $26 \%$ of the $\left[{ }^{14} \mathrm{C}\right]$ methanol, and $12.6 \%$ of the terminal methyl group of $\left[\right.$ methyl $\left.-{ }^{14} \mathrm{C}\right]$ methionine, were converted to ${ }^{14} \mathrm{CH}_{4}$ without any lag period for adaptation. We do not at the moment have adequate analytical techniques for sedimentary concentrations of these $\mathrm{CH}_{4}$ precursors and so, unlike $\mathrm{HCO}_{3}^{-}$and acetate, we cannot at present determine the quantitative contribution of each of these precursors to the additional $\mathrm{CH}_{4}$ formed in the presence of molybdate. The results clearly show, however, that formaldehyde, methanol and methionine were converted to $\mathrm{CH}_{4}$ in the presence of molybdate and these must therefore be strong candidates as the source of the extra $\mathrm{CH}_{4}$. In agreement with these findings, it is interesting to note that Oremland et al. $(1982 a)$ have recently shown that methanogenesis from sediment in Big Soda Lake, Nevada, was stimulated by addition of methanol, trimethylamine, and methionine, but not by addition of $\mathrm{H}_{2}$, acetate or formate. Oremland et al. $(1982 b)$ have also demonstrated that the majority of $\mathrm{CH}_{4}$ from a North American saltmarsh sediment was from methanol and methylated amines, not from acetate or $\mathrm{HCO}_{3}^{-}$. These workers suggested that sulphate-reducing and methanogenic bacteria did not compete for methanol which was used only for methane formation. In contrast, our results suggest competition even for methanol in the Colne Point sediment, and sulphate-reducing bacteria are known to utilize it as an electron donor (Postgate, 1979).

One further hypothesis to explain the additional $\mathrm{CH}_{4}$ in the presence of molybdate needed to be considered. Recent work (Davis \& Yarborough, 1966; Reeburgh, 1980; Devol \& Ahmed, 1981 ; Iversen \& Blackburn, 1981) has suggested that sulphate-reducing bacteria may oxidize $\mathrm{CH}_{4}$ anaerobically. The apparent stimulation by molybdate of $\mathrm{CH}_{4}$ accumulation in the gas head spaces of flasks could also have been explained, therefore, if molybdate addition inhibited 
oxidation of $\mathrm{CH}_{4}$ by sulphate-reducing bacteria rather than stimulated $\mathrm{CH}_{4}$ formation. However, the result of the experiment with added ${ }^{14} \mathrm{CH}_{4}$ discounted this hypothesis as no removal of ${ }^{14} \mathrm{CH}_{4}$ by bacteria in the slurry could be detected.

Our observations do not necessarily contradict the general hypothesis that competition by the sulphate-reducers for $\mathrm{H}_{2}$ and acetate inhibits $\mathrm{CH}_{4}$ formation from these precursors. Under conditions of such competition in the presence of sulphate it might be expected that only small populations of methanogenic bacteria would normally be present in the sediment, metabolizing these substrates at very low rates of activity. Senior et al. (1982) have shown, for example, that methanogenesis from $\mathrm{H}^{14} \mathrm{CO}_{3}^{-}$proceeds in the Colne Point saltmarsh sediment, but only at rates three orders of magnitude lower than the rates of sulphate reduction. Again, in marine sediments acetate is converted to $\mathrm{CO}_{2}$ not $\mathrm{CH}_{4}$ (Banat et al., 1981; Sørenisen et al., 1981), whereas in freshwater sediments acetate is a precursor of $\mathrm{CH}_{4}$ (Cappenberg \& Prins, 1974; Winfrey \& Zeikus, 1979). Thus, molybdate addition to sulphate-rich sediments may not result in any great or immediate stimulation of either the $\mathrm{H}_{2}+\mathrm{CO}_{2}$ or the acetate pathways to $\mathrm{CH}_{4}$, until the methanogenic bacterial populations have time to develop in response to the greater availability of these substrates. Such a development of the $\mathrm{H}_{2}+\mathrm{CO}_{2}$ pathways to $\mathrm{CH}_{4}$ was seen after $8 \mathrm{~d}$ in our first experiment (Fig. 1).

Only Methanosarcina barkeri and Methanococcus mazei are known to metabolize methanol (Weimer \& Zeikus, 1978; Hippe et al., 1979). The latter organism has been isolated from Colne Point saltmarsh sediment (Abram \& Nedwell, 1978a). It has been demonstrated that methanol is converted much more rapidly to methane by Methanosarcina barkeri than is $\mathrm{H}_{2}+\mathrm{CO}_{2}$ or acetate (Hutten et al., 1980). Thus the rate at which methanol may be converted to methane may be less restricted by a small methanogenic population size than is the conversion of $\mathrm{H}_{2}+\mathrm{CO}_{2}$.

Thus the addition of $20 \mathrm{~mm}$-molybdate would seem to stimulate methanogenesis by a twofold process. Firstly, precursors of $\mathrm{CH}_{4}$ which are usually oxidized to $\mathrm{CO}_{2}$ are made available to methanogenic bacteria by the addition of molybdate. These include formaldehyde, methanol and methionine, but not acetate or formate. The $\mathrm{H}_{2}+\mathrm{CO}_{2}$ pathway to $\mathrm{CH}_{4}$ is also stimulated to a limited extent. Secondly, the longer term development of a larger methanogenic bacterial population is permitted because of the removal of competitive inhibition by the sulphatereducing bacteria.

We wish to thank NERC, U.K., for financial support.

\section{REFERENCES}

ABRAM, J. W. \& NeDWELL, D. B. (1978a). Inhibition of methanogenesis by sulphate reducing bacteria competing for transferred hydrogen. Archives for Microbiology 117, 89-92.

Abram, J. W. \& NeDWelL, D. B. (1978b). Hydrogen as a substrate for methanogenesis and sulphate reduction in anaerobic saltmarsh sediment. Archives for Microbiology 117, 93-97.

BALBA, M. T. \& Nedwell, D. B. (1982). Microbial metabolism of acetate, propionate and butyrate in anoxic sediment from the Colne Point Saltmarsh, Essex, U.K. Journal of General Microbiology 128, 1415-1422.

Banat, I. M., Lindström, E. B., Nedwell, D. B. \& BALBA, M. T. (1981). Evidence for the coexistence of two distinct functional groups of sulfate-reducing bacteria in salt marsh sediment. Applied and Environmental Microbiology 42, 985-992.

BAUCHOP, T. (1967). Inhibition of rumen methanogenesis by methane analogues. Journal of Bacteriology 94, 171-175.
Cappenberg, T. E. \& Prins, R. A. (1974). Interrelations between sulphate-reducing and methane-producing bacteria in bottom deposits of a freshwater lake. III. Experiments with ${ }^{14} \mathrm{C}$-labelled substrates. Antonie van Leeuwenhoek Journal of Microbiology 40, 457-469.

DAvis, J. B. \& YARBorough, H. E. (1966). Anaerobic oxidation of hydrocarbons of Desulfovibrio desulfuricans. Chemical Geology 1, 137-146.

Devol, A. H. \& AHMED, S. I. (1981). Are high rates of sulphate reduction associated with anaerobic oxidation of methane? Nature, London 291, 407-408.

GraN, G. (1952). Determination of the equivalence point in potentiometric titrations. Analyst 77, 661671.

Hippe, H., Caspari, D., Fiebig, K. \& Gottschalk, G. (1979). Utilization of trimethylamine and other $\mathrm{N}$ methyl compounds for growth and methane formation by Methanosarcina barkeri. Proceedings of the National Academy of Sciences of the United States of America 76, 494-498. 
Hutten, T. J., BongaerTs, H. C. M., VAN DER DRIFT, C. \& Vogels, G. D. (1980). Acetate, methanol and carbon dioxide as substrates for growth of Methanosarcina barkeri. Antonie van Leeuwenhoek Journal of Microbiology 46, 601-610.

IVERSEN, N. \& BlaCKBURN, T. H. (1981). Seasonal rates of methane oxidation in anoxic marine sediments. Applied and Environmental Microbiology 41, 1295-1300.

KING, G. M. \& WIEBE, W. J. (1980). Tracer analysis of methanogenesis in saltmarsh soil. Applied and Environmental Microbiology 39, 877-881.

NeDWell, D. B. \& ABRAM, J. W. (1978). Bacterial sulphate reduction in relation to sulphur geochemistry in two contrasting areas of saltmarsh sediment. Estuarine and Coastal Marine Science 6, 341-351.

NedWell, D. B. \& BANAT, I. M. (1981). Hydrogen as an electron donor for sulfate-reducing bacteria in slurries of saltmarsh sediment. Microbial Ecology 7, 305-313.

Oremland, R. S. \& TaYlor, B. F. (1978). Sulfate reduction and methanogenesis in marine sediments. Geochimica et cosmochimica acta 42, 209-214.

Oremland, R. S., Marsh, L. M. \& Desmarais, D. J (1982a). Methanogenesis in Big Soda Lake, Nevada: an alkaline, moderately hypersaline desert lake. Applied and Environmental Microbiology 43, 462-468.

Oremland, R. S., Marsh, L. M. \& PolCin, S. (1982b). Methane production and simultaneous sulphate reduction in anoxic saltmarsh sediments. Nature, London 296, 143-145.

PeCK, H. D. (1959). The ATP-dependent reduction of sulfate with hydrogen in extracts of Desulfovibrio desulfuricans. Proceedings of the National Academy of Sciences of the United States of America 45, 701-708.

Postgate, J. R. (1979). The Sulphate-Reducing Bacteria. Cambridge: Cambridge University Press.
REEBURGH, W. S. (1980). Anaerobic methane oxidation: rate depth distributions in Skan Bay sediments. Earth and Planetary Science Letters 47, 345-352.

SENioR, E., LINDSTRöm, E. B., BANAT, I. M. \& NeDWELl, D. B. (1982). Sulfate reduction and methanogenesis in the sediment of a saltmarsh on the east coast of the United Kingdom. Applied and Environmental Microbiology 43, 987-996.

Sørensen, J., Christensen, D. \& Jørgensen, B. B. (1981). Volatile fatty acids and hydrogen as substrates for sulfate-reducing bacteria in anaerobic marine sediment. Applied and Environmental Microbiology 42, 5-11.

WeIMER, P. J. \& ZeIKus, J. G. (1978). One carbon metabolism in methanogenic bacteria. Cellular characterization and growth of Methanosarcina barkeri. Archives for Microbiology 119, 49-57.

WINFREY, M. R. \& ZeIKUS, J. G. (1977). Effect of sulfate on carbon and electron flow during microbial methanogenesis in freshwater sediments. Applied and Environmental Microbiology 33, 275-281.

WINFREY, M. R. \& ZeIKUS, J. G. (1979). Anaerobic metabolism of immediate methane precursors in Lake Mendota. Applied and Environmental Biology 37, 244-253.

WOLFE, R. S. (1971). Microbial formation of methane. Advances in Microbial Physiology 6, 107-146.

Wolfe, R. S. \& HigGins, I. J. (1979). Microbial biochemistry of methane - a study in contrasts. In Microbial Biochemistry, International Review of Biochemistry, vol. 21, pp. 268-300. Edited by J. R. Quayle. Baltimore: University Park Press.

ZINDER, S. H. \& BROCK, T. D. (1978). Methane, carbon dioxide, and hydrogen sulfide production from the terminal methiol group of methionine by anaerobic lake sediments. Applied and Environmental Microbiology, 35, 344-352. 